\title{
E-Commerce Evaluation and E Business Trends
}

\author{
Premkumar Balaraman, Kalpana Kosalram \\ School of Management, SRM University, Vadapalani,Chennai 600026, India \\ premkumar.b@vdp.srmuniv.ac.in,kalpax4@gmail.com
}

\begin{abstract}
E-Commerce in recent times has exploded many folds due to the invention of new Information and Communication (ICT) technologies and applications. Business models of today are highly depending upon internet based transaction and trading platforms, use of Web portals and mobile applications. Proposition of new business models sans the inclusion of internet and their application has become almost impossible for business. Business data pertaining to $\mathrm{E}$ Commerce has become highly valuable in recent times. Social networking websites, sharing of product data and its reviews in blogs paves ways for promoting business in new methods. There is need to develop metrics to assess the strength of $\mathrm{E}$ Commerce penetration in Business and also evaluate the various $\mathrm{E}$ Commerce platforms. Use of $\mathrm{E}$ business tools for data analysis, prediction and decision making has become the latest order of the day. Changing trends in $\mathrm{E}$ business has a drastic impact on the organizations depending upon internet based applications for handling its business processes and day to day transactions.
\end{abstract}

Index Terms - E-Commerce, ICT, Business Model, E -Commerce Metrics, E-Business

\section{INTRODUCTION}

The impact of information and communication technology on varied areas of the Global economy and current trends in e business is an area of research that could lead to valuable business insights. The adaptation of business models to accommodate the customer's needs for providing an internet based business transaction platform is a reality and a compulsion for business as an order of the day. With so much necessity for business houses to include internet based marketing and applications to support one's business process and customer expectations, the area of $\mathrm{E}$ commerce and it's evaluation from a commercial perspective is still under researched.

The survey data from various sources of information is gathered and analyzed in the paper pertaining to internet based surveys, adoption of e commerce, e business trends and technology in order to assess e commerce success. Also the various terminologies and models on E commerce are clarified theoretically for better understanding for future researchers. Today retail organizations are once again seeing a transformation in the way they do business, thanks to Web 2.0.

The internet-or "splinternet" as Forrester Research (2010) calls it - has exploded. In a study by Oracle (2012), it is found that although e-mail campaigns still represent the most significant portion of the mix, one surprising finding was that 46 percent of the respondents stated that they're measuring social channel customer feedback - meaning that nearly half of the respondents monitor and measure comments posted on Twitter, Facebook, and even personal blogs (refer table 1).

Table 1 - E-Commerce Analytics Trends

\begin{tabular}{|c|c|}
\hline Email Campaign Effectiveness & $74 \%$ \\
\hline Natural / SEO search rankings & $70 \%$ \\
\hline Paid search/SEM effectiveness & $61 \%$ \\
\hline Onsite search effectiveness & $56 \%$ \\
\hline Customized landing page effectiveness & $55 \%$ \\
\hline Social channel customer feedback & $46 \%$ \\
\hline A/B testing & $40 \%$ \\
\hline Cross-sell/up-sell merchandising & $34 \%$ \\
\hline Cross-channel program effectiveness & $25 \%$ \\
\hline $\begin{array}{c}\text { Loyalty program effectiveness } \\
\text { Other }\end{array}$ & $14 \%$ \\
\hline
\end{tabular}

The Research paper starts with an introduction to the topic on Ecommerce evaluation and trends. The objective of the study and research methodology is explained in the initial sections of the paper. The various perceptions on business models clarifies on understanding of business modeling and how Information technology cannot be separated from business modeling in growing globalized business. The 
term E Business is applied more in generic sense for any application of information technology into business processes and hence it is explained and discussed from the view point of business modeling. Narrowing further into specific area of $\mathrm{E}$ commerce the research paper discusses on the $\mathrm{E}$ commerce metrics and elaborates on considerations of factors for evaluating $\mathrm{E}$ commerce platforms and applications. The top 10 trends in shaping the future of $\mathrm{E}$ commerce and the trends in $\mathrm{E}$ business evidenced in the later part of the paper serve as an eye opener for IT managers and e - tailers.

\subsection{OBJECTIVE OF THE STUDY}

$>$ To find out the metrics and criteria of evaluating E commerce platforms

$>$ To assess the trends in $\mathrm{E}$ business and its impact on Business processes

\section{RESEARCH METHODOLOGY}

The study is qualitative and descriptive in nature and most of the data is based on secondary sources of survey data. Such an approach is adopted in the study as the area of research is very broad and sources of data are also spread across multiple locations. To arrive at a conclusive idea of the larger picture on E- Business trends, analyzing the existing survey data would give a better result in finding the answers to the research question framed.

\section{BUSINESS MODELS \& INFORMATION TECHNOLOGY}

In today's fast paced business environment there are varied perceptions on Business model and its definitions.

According to Applegate (2001), Business model is a description of a complex business that enables study of its structure, the relationships among structural elements, and how it will respond to the real world. Business model (Petrovic et al., 2001, Auer \& Follack, 2002) is a description of the logic of a "business system" for creating value that lies behind the actual processes. And with growing use of Information technology for creating a competitive edge in business, even the definition of business model can include the idea of use of $\mathrm{e}$ commerce for Business modeling.

According to Osterwalder \& Pigneur (2002), Business model is a description of the value a company offers to one or several segments of customers and the architecture of the firm and its network of partners for creating, marketing and delivering this value and relationship capital, in order to generate profitable and sustainable revenues streams. Shaffer, Smith and Linder (2005) uncovered twelve definitions published from 1998 to 2002, and they developed an affinity diagram to identify four major categories common to all or most definitions: strategic choices, creating value, capturing value and the value network.

A great deal of research has been directed towards classifying business models and grouping them into specific categories. The business models belonging to the same category usually share some common characteristics, such as the same pricing policy or the same customer relationship model (Pateli and Giaglis, 2003). Hayes el. al (2005) by combining the work of Ticoll et al. (1998), Timmers (1999), and Kaplan and Sawhney (2000) proposed that electronic business models could be classified according to how they exhibit varying degrees of economic control, value chain integration, functional integration, business innovation and technical innovation. They developed the prerequisites framework for assisting decision makers assess the suitability of electronic business models during the intelligence phase of the decision making process and not in other phases. The basis of their prerequisites model is shown in Table 2. This framework hypothesizes that a particular business model is more likely to succeed in a particular industrial sector when the characteristics of the sector match the conditions required for the model.

Table 2 - Characteristics of E-Business Models (Hayes,J., \& Finnegan,P., 2005)

\begin{tabular}{|c|c|c|c|c|c|}
\hline $\begin{array}{l}\text { Busines } \\
\text { s model }\end{array}$ & $\begin{array}{l}\text { Econ } \\
\text { omic } \\
\text { Contr } \\
\text { ol }\end{array}$ & $\begin{array}{l}\text { Funct } \\
\text { ional } \\
\text { Integr } \\
\text { ation }\end{array}$ & $\begin{array}{l}\text { Suppl } \\
\mathrm{y} \\
\text { chain } \\
\text { Integr } \\
\text { ation }\end{array}$ & $\begin{array}{l}\text { Innov } \\
\text { ation }\end{array}$ & Sourcing \\
\hline E-shop & Low & Low & Low & Low & $\begin{array}{l}\text { Systema } \\
\text { tic }\end{array}$ \\
\hline E-mall & Low & $\begin{array}{l}\text { Medi } \\
\text { um }\end{array}$ & Low & $\begin{array}{l}\text { Medi } \\
\text { um }\end{array}$ & $\begin{array}{l}\text { Systema } \\
\text { tic }\end{array}$ \\
\hline $\begin{array}{l}\text { E-procu } \\
\text { rement }\end{array}$ & $\begin{array}{l}\text { Medi } \\
\text { um }\end{array}$ & $\begin{array}{l}\text { Medi } \\
\text { um }\end{array}$ & $\begin{array}{l}\text { Medi } \\
\text { um }\end{array}$ & $\begin{array}{l}\text { Medi } \\
\text { um }\end{array}$ & $\begin{array}{l}\text { Systema } \\
\text { tic }\end{array}$ \\
\hline $\begin{array}{l}\text { E-auctio } \\
\mathrm{n}\end{array}$ & Low & $\begin{array}{l}\text { Medi } \\
\text { um }\end{array}$ & $\begin{array}{l}\text { Medi } \\
\text { um }\end{array}$ & $\begin{array}{l}\text { Medi } \\
\text { um }\end{array}$ & $\begin{array}{l}\text { Spot/sys } \\
\text { tematic }\end{array}$ \\
\hline $\begin{array}{l}\text { Informa } \\
\text { tion } \\
\text { brokera } \\
\text { ge }\end{array}$ & Low & Low & Low & High & $\begin{array}{l}\text { Not } \\
\text { applicab } \\
\text { le }\end{array}$ \\
\hline $\begin{array}{l}\text { Trust } \\
\text { services }\end{array}$ & Low & Low & Low & $\begin{array}{l}\text { Medi } \\
\text { um }\end{array}$ & $\begin{array}{l}\text { Not } \\
\text { applicab } \\
\text { le }\end{array}$ \\
\hline $\begin{array}{l}3^{\text {rd }} \text { party } \\
\text { marketp } \\
\text { lace }\end{array}$ & High & High & High & High & $\begin{array}{l}\text { Spot/sys } \\
\text { tematic }\end{array}$ \\
\hline
\end{tabular}




\begin{tabular}{|l|l|l|l|l|l|}
\hline E-hubs & High & High & High & $\begin{array}{l}\text { Hi } \\
\text { gh }\end{array}$ & $\begin{array}{l}\text { Spot/syste } \\
\text { matic }\end{array}$ \\
\hline $\begin{array}{l}\text { Virtual } \\
\text { communi } \\
\text { ties }\end{array}$ & Medi & Medi & High & $\begin{array}{l}\text { Hi } \\
\text { um }\end{array}$ & $\begin{array}{l}\text { Not } \\
\text { applicable }\end{array}$ \\
\hline $\begin{array}{l}\text { Value-ch } \\
\text { ain } \\
\text { integrato } \\
\text { rs }\end{array}$ & High & High & High & $\begin{array}{l}\text { Hi } \\
\text { gh }\end{array}$ & $\begin{array}{l}\text { Not } \\
\text { applicable }\end{array}$ \\
\hline $\begin{array}{l}\text { Value-ch } \\
\text { ain } \\
\text { service } \\
\text { providers }\end{array}$ & Low & Medi & Medi & Hi & Not \\
\hline $\begin{array}{l}\text { Collabor } \\
\text { ation } \\
\text { platforms }\end{array}$ & Low & High & High & Hi & Not \\
\hline
\end{tabular}

\section{E-COMMERCE}

In its broadest sense, the term e-business is usually understood as the application of information technologies (IT) into a business process. Despite various terminological problems, the notion of e-business extends the more narrow understanding expressed with the term "e-commerce" (Turban et al., 2004). E-business has often been studied from the technical (information and communication technology) (Pastuszak, 2003), organizational, managerial (Pastuszak, 2004) or legislative aspects, while there are fewer studies that deal with the economic aspects and with the corresponding evaluation.

\subsection{E-Commerce metrics}

A very useful representation of needs for e-commerce metrics as related to the three areas of the $S$ shaped path for the diffusion of new technologies is presented in Figure 1. The idea is that there is a life cycle for research needs which follows the pattern of growth of e-commerce markets: at an initial stage there is need for information on the enabling factors and barriers to e-commerce; at a more mature stage one should look for the intensity of e-commerce use to enable policy makers to address imbalances; at a later stage one would be able to measure the impact of e-commerce on the economy and society. The three broad areas for indicators are:

1. E-commerce readiness - Included here are issues of preparing the technical, commercial and social infrastructures that are necessary to support e-commerce. It is essential for each country to be able to construct a statistical picture of the state of readiness of each infrastructure element to engage with e-commerce.
2. E-commerce intensity - These issues relate to the state of e-commerce usage, volume, value and nature of the transactions. The statistical requirement is to profile who is exploiting e-commerce possibilities and who is not, and to identify leading sectors and applications.

3. E-commerce impact - These issues relate to additionality (i.e. e-commerce goes beyond substitution effects and creates new value added) and multiplier effects. Statistics are needed to evaluate whether and to what extent e-commerce makes some kind of difference in terms of efficiency and/or the creation of new sources of wealth.

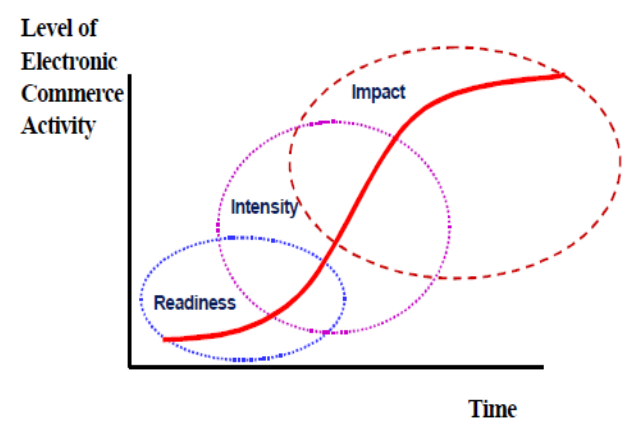

Figure 1 - Level of E - Commerce

The degree of e-commerce readiness should encompass indicators that reflect the country's socio-economic and technological infrastructure and usage. Particularly important are indicators that express the potential for e-commerce readiness, i.e. the propensity of individuals or businesses or governments to transact or more generally to carry out businesses electronically (e.g. indicators of credit card use, indicators of the barriers or the perceived benefits to e-commerce). The e-intensity indicators would give information on the size, growth and nature of the electronic commerce transactions/business.

It is important to know for what component of transaction e- commerce is used (e.g. information gathering, sale, purchase, payment) or in what business function; who are the actors involved in the transaction/business and what their socio-demographic characteristics are; what are the products and services involved, whether the transaction is domestic, international, urban or rural. The impact indicators would focus on the additionality and multiplier effects of e-commerce, the impacts on production processes and business models, on the workplace and more generally on society.

Based on the lines of e commerce metrics as defined, the real status of ecommerce metrics in the member countries of Organisation for Economic Co-operation and Development (OECD), was presented and compared by Alessandra Colecchia (2000). In the figure 2 , the darker shade indicates availability across all OECD countries; the lighter shade indicates availability across a limited number of countries (more than three); 
no shade indicates a very limited availability (one to three countries).

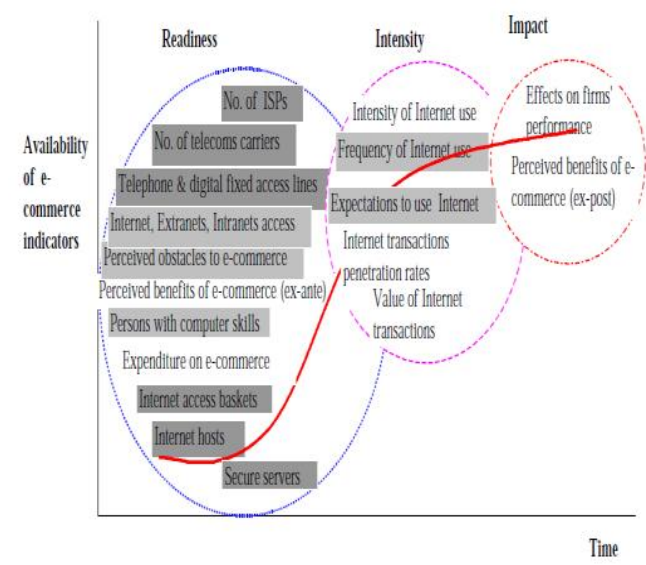

Figure 2 - Availability of e-commerce indicators across OECD countries

\subsection{Evaluating E - commerce platforms}

Selecting the right e-commerce application for the long term can be a difficult exercise. It's not easy to base a decision on both current requirements and a vague, undetermined set of future needs that have not yet even hit the planning stages. The difference between e-commerce application capabilities can spell the difference between an e-commerce site's success and failure. The white paper by Oracle (2011) offers 10 considerations to help guide the selection criteria for the next e- commerce platform - which should be the last e-commerce platform anyone ever needs to buy (table 3).

Table 3 - The Top 10 Technical Considerations for Evaluating E-Commerce Platforms

\begin{tabular}{|c|l|l|}
\hline $\begin{array}{c}\text { S. } \\
\text { N } \\
\text { o }\end{array}$ & Factor & \multicolumn{1}{|c|}{ What is the Factor? } \\
\hline 1. & Scalability & $\begin{array}{l}\text { Will the site perform } \\
\text { efficiently through traffic } \\
\text { peaks and valleys? }\end{array}$ \\
\hline 2. & $\begin{array}{l}\text { The } \\
\text { Product } \\
\text { Catalog }\end{array}$ & $\begin{array}{l}\text { Will today's catalog schema } \\
\text { meet tomorrow's demands? }\end{array}$ \\
\hline 3. & $\begin{array}{l}\text { Business } \\
\text { User }\end{array}$ & $\begin{array}{l}\text { Will my application directly } \\
\text { empower my merchandisers, } \\
\text { marketing managers, and } \\
\text { other business owners? }\end{array}$ \\
\hline 4. & Search & $\begin{array}{l}\text { How easily can customers } \\
\text { find what they want, and how }\end{array}$ \\
\hline
\end{tabular}

\begin{tabular}{|c|c|c|}
\hline & & $\begin{array}{l}\text { easily can I promote the } \\
\text { products I want to push based } \\
\text { on customer searches? }\end{array}$ \\
\hline 5. & Agility & $\begin{array}{l}\text { How easily can I implement } \\
\text { business requests to monitor } \\
\text { and respond to an individual } \\
\text { Web visitor's behavior? }\end{array}$ \\
\hline 6. & $\begin{array}{l}\text { Reporting } \\
\text { and } \\
\text { Analytics }\end{array}$ & $\begin{array}{l}\text { Do I have all the features I } \\
\text { need to understand my online } \\
\text { business? (How does the site } \\
\text { capture and store both historic } \\
\text { and behavioral data?) }\end{array}$ \\
\hline 7. & Standards & $\begin{array}{l}\text { Is the application built on a } \\
\text { standards-based platform? } \\
\text { (Java/J2EE or } \\
\text { Microsoft .NET architecture) }\end{array}$ \\
\hline 8. & Integration & $\begin{array}{l}\text { How easily can the } \\
\text { application integrate with my } \\
\text { other systems? }\end{array}$ \\
\hline 9. & $\begin{array}{l}\text { Interopera } \\
\text { bility }\end{array}$ & $\begin{array}{l}\text { Does the application function } \\
\text { within a service-oriented } \\
\text { architecture? }\end{array}$ \\
\hline 10 & Synergy & $\begin{array}{l}\text { Will the application support } \\
\text { business models beyond B2C } \\
\text { e-commerce? }\end{array}$ \\
\hline
\end{tabular}

\subsection{E - Commerce trends}

According to Michael Piastro (2010), the top 10 trends shaping the future of ecommerce are summarized in the table 4.

Table 4 - Top 10 trends shaping the future of E Commerce

\begin{tabular}{|c|l|l|}
\hline $\begin{array}{c}\text { S. } \\
\text { N } \\
\text { o }\end{array}$ & \multicolumn{1}{|c|}{ Trend } & \multicolumn{1}{|c|}{ What is the Trend? } \\
\hline 1. & $\begin{array}{l}\text { Collective } \\
\text { intelligenc } \\
\text { e }\end{array}$ & $\begin{array}{l}\text { When a customer visits a site } \\
\text { a shopper's persona is } \\
\text { interactions... }\end{array}$ \\
\hline 2. & $\begin{array}{l}\text { Social } \\
\text { network } \\
\text { integration }\end{array}$ & $\begin{array}{l}\text { Integrating a "share" button } \\
\text { enables users to share content } \\
\text { to their social networking site }\end{array}$ \\
\hline 3. & $\begin{array}{l}\text { Mobile } \\
\text { sites }\end{array}$ & $\begin{array}{l}\text { A dedicated mobile site } \\
\text { experience is a must }\end{array}$ \\
\hline
\end{tabular}




\begin{tabular}{|c|c|c|}
\hline 4. & $\begin{array}{l}\text { Location- } \\
\text { based } \\
\text { tie-ins }\end{array}$ & $\begin{array}{l}\text { GPS capabilities of mobile } \\
\text { devices usher in a new era of } \\
\text { exciting cross-channel } \\
\text { promotion capabilities. }\end{array}$ \\
\hline 5. & $\begin{array}{l}\text { Experienti } \\
\text { al user } \\
\text { interface }\end{array}$ & $\begin{array}{l}\text { Beyond simply being easy to } \\
\text { use, modern ecommerce sites } \\
\text { for innovative brands can be } \\
\text { experiential and immersive, }\end{array}$ \\
\hline 6. & $\begin{array}{l}\text { Contextual } \\
\text { visualizati } \\
\text { on }\end{array}$ & $\begin{array}{l}\text { Shoppers increasingly expect } \\
\text { to visualize how a product will } \\
\text { fit into their life and style. }\end{array}$ \\
\hline 7. & $\begin{array}{l}\text { Dynamic } \\
\text { grid } \\
\text { expansion } \\
\text { and liquid } \\
\text { layouts }\end{array}$ & $\begin{array}{l}\text { Utilize liquid layouts to } \\
\text { automatically size your } \\
\text { product display based on the } \\
\text { shoppers' resolution. }\end{array}$ \\
\hline 8. & $\begin{array}{l}\text { Minimize } \\
\text { UI cruft }\end{array}$ & $\begin{array}{l}\text { Shoppers come to your site to } \\
\text { see your products, not your } \\
\text { fancy navigation systems. }\end{array}$ \\
\hline 9. & $\begin{array}{l}\text { Rich } \\
\text { DHTML } \\
\text { and AJAX }\end{array}$ & $\begin{array}{l}\text { Instead of having to reload a } \\
\text { page every time the shopper } \\
\text { clicks, these technologies } \\
\text { enable a world of rich } \\
\text { interactions (instantaneously) }\end{array}$ \\
\hline 10 & Get textual & $\begin{array}{l}\text { With the advent of HTML5 } \\
\text { and font-serving technologies } \\
\text { such as TypeKit, the web } \\
\text { designers' typographic palette } \\
\text { has been opened up as never } \\
\text { before. }\end{array}$ \\
\hline
\end{tabular}

In November 2011, Endeca (acquired by Oracle in February 2012) conducted the Trends for 2012 in Business to Consumer (B2C) Commerce survey to help businesses gain actionable insight into the evolving nature of e-commerce. When asked to identify the top three areas for investment in 2012, the respondents indicated that continued investment in the customer experience was the top priority, followed by mobile and commerce platforms (refer figure 3 ).

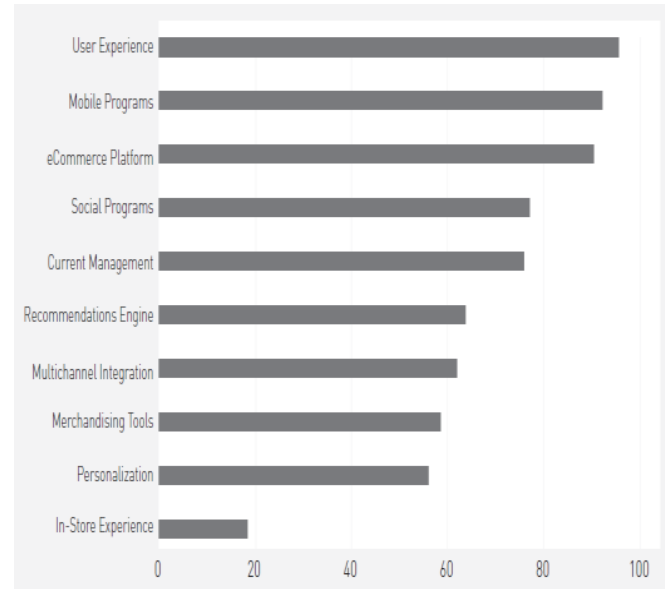

Figure 3 - Trends for 2012 in Business to Consumer (B2C) Commerce survey - Oracle Survey, 2012.

Broken out from "other social programs," Facebook takes the top spot for emerging areas to invest in, with 57 percent of the respondents indicating a planned investment in the social networking giant. Behind Facebook, the mobile Web (47 percent), other social programs (such as Twitter or forums, with 43 percent), and mobile apps (43 percent) rank among the top emerging initiatives (refer figure 4).

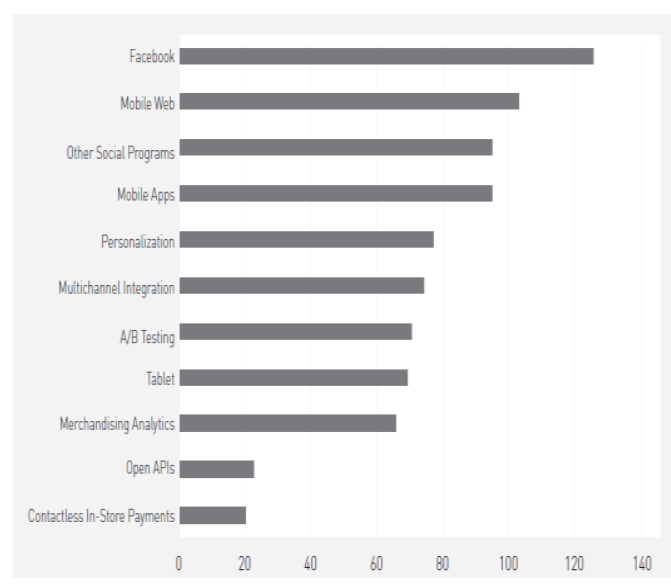

Figure 4 - Impact of Facebook, mobile Web and other social programs - Oracle Survey, 2012.

\section{E BUSINESS IN REALTIME}

As an alternative strategy adopted to reach the small businesses, some Information and Communication Technology (ICT) layers offer the software on demand through online access. While the road to Internet-based Software as a Service (SAAS) was a bumpy one in the early days, online services have become a credible - and often desirable - alternative to packaged software. SAAS layers are thriving in multiple market segments, from the Small and Medium Business (SMB) segment 
to the large enterprise sector, and in almost every application category.

As Internet-based computing becomes viable for an increasing array of individual and business requirements, customers can focus more on getting the functionality and outcomes they need from the application, and less on the underlying operating system, middleware and infrastructure requirements. The trend for the SAAS industry development is for growth, as top players such as Microsoft, Google, IBM and salesforce.com battle to build SAAS systems. At the same time, new SAAS players and solutions will continue to emerge, and the likelihood of any one player dominating this landscape is very low.

\subsection{Changing Market Share of Major Software Applications}

Open source software is currently more widely in use on the server than on the desktop. In the domain of webservers, open source software is clearly the market leader. According to Netcraft's survey (2012), the open source webserver Apache had $61.45 \%$ market share (Microsoft IIS had 14.62\%). In 2004, the total market share of Linux on the PC market was estimated by IDC to be around 5\%, projected to reach around 7\% in 2008 (37) (which would mean it would overtake the market share of Mac OS which is around 6\%). However, Linux is much stronger in use on servers than desktops, estimations for its market share in the server segment are as high as around $30 \%$, also it's the most popular operating system to be installed on newly bought or installed servers.

For mail servers, the research done by Falko Timme (2004) shows a market share of popular open source mail servers such as Sendmail or Exim of around 50\% (refer Figure 5). The market share of Microsoft's browser has been declining ever since 2004 (Thecounter, 2007), and it's currently around $71 \%$ while Mozilla Firefox has now around 12\% market share (39) and continues growing significantly. The market for office suites is still dominated by Microsoft Office, but Open Office is getting increasingly popular, particularly with SMEs.

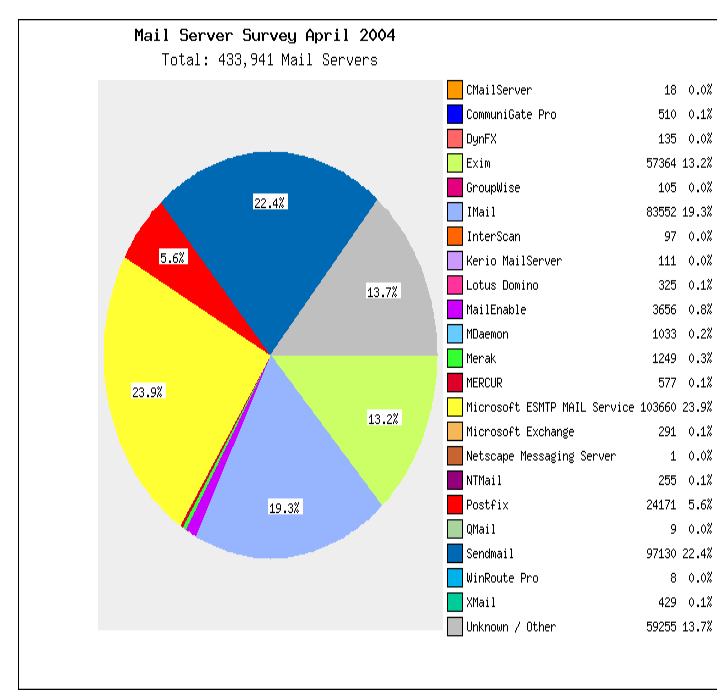

Figure 5 - Falko Timme - Mail Server Survey (2004).

5.2 The Top Ten E-Business Trends for the 21st Century

The top ten trends in E - Business was proposed by Globalfuturist (2004). E-business will become a critical competitive strategy that will revolutionize the global economy.

$>$ Companies will learn to manage customers' relationships by virtually serving their needs "24 × 7"-24 hours a day, 7 days a week.

$>$ E-business that enables customers to personalize and customize products or services will flourish.

$>$ Using the Net to find new customers and to better target customer preferences will be a standard practice.

$>$ Producing, marketing, and distributing products or services online will be a cost-effective strategy for business.

$>$ Learning to develop and serve online communities with niche interests will be essential to building customer loyalty.

$>$ E-business models that provide greater choice for customers will change the traditional economics of supply and demand.

$>$ Ready access to the Net from multiple gateways-cable TV, satellite, wireless telephones, and other devices-will greatly expand e-business opportunities.

$>$ Highly efficient e-business virtual supply chains will intimately link manufacturers and producers directly to customers.

$>$ E-business will reach over one billion people and generate more than $\$ 2$ trillion in revenues worldwide by 2005 .

\section{REFERENCES}


[1] Alessandra Colecchia (2000). Defining and measuring Electronic Commerce - Towards the development of an OECD methodology, Organisation for Economic Co-operation and Development (OECD). Accessed from: http://www.singstat.gov.sg/statsres/conferences/eco mmerce/d8.pdf

[2] Applegate, L. M. (2001). E-business Models: Making sense of the Internet business landscape, In G.Dickson, W. Gary, and G. DeSanctis (Eds.), Information Technology and the future enterprise: New models for managers, Upper Saddle River, N.J.: Prentice Hall.

[3] Auer, C. \& Follack, M. (2002).Using Action Research for Gaining Competitive Advantage out of the Internet's Impact on Existing Business Models, In the Proceedings of the 15th Bled Electronic Commerce Conference - eReality: Constructing the eEconomy, Bled, Slovenia, June 17 - 19, pp.767-784., 2002.

[4] Falko Timme (2004). Mail Server Survey. Accessed from:

http://www.falkotimme.com/projects/survey_smtp. php

[5] Forrester Research. (2010). "The Splinternet: Preparing for an Internet Fragmented by Devices and Passwords," January 26, 2010; www.forrester.com/rb/Research/splinternet/q/id/56 $303 / \mathrm{t} / 2$

[6] Hayes, J. \& Finnegan, P. (2005). “Assessing the of Potential of e-Business Models: Towards a Framework for Assisting Decision-Makers," European Journal of Operations Research, (160), 365-379.

[7] Globalfuturist (2004). Top ten E Business trends. Accessed from: http://www.globalfuturist.com/about-igf/top-ten-tre nds/top-ten-ebusiness-trends-for-the-21st-century.ht $\mathrm{ml}$

[8] IDC (2004). Linux market overview. Accessed from: http://pascal.case.unibz.it/retrieve/1281/linux_mark et_overview.pdf

[9] Kaplan, S., Sawhney, M. (2000). E-hubs: The new B2B marketplaces. Harvard Business Review (May-June), 97- 103.

[10] Michael Piastro (2010). The top 10 trends shaping the future of ecommerce. Accessed from: http://www.imediaconnection.com/content/27969.a $\mathrm{sp}$

[11] Netcraft (2012). Market Share for Top Servers Across All Domains August 1995 - July 2012 - July 2012 Web Server Survey. Accessed from: http://news.netcraft.com/archives/2007/04/02/april_ 2007_web_server_survey.html

[12] Oracle (2011). The Top 10 Technical Considerations for Evaluating E-Commerce Platforms. Oracle White Paper. March 2011. Accessed from: http://www.oracle.com/us/products/applications/atg /top-10-considerations-ecommerce-333324.pdf
[13] Oracle. (2012). E-Commerce Analytics Trends for 2012. An Oracle White Paper February 2012, pp.3-4. Accessed from: http://www.oracle.com/us/products/applications/ web-commerce/ecommerce-analytics-trends-2012 -1504948.pdf

[14] Osterwalder, A., \& Pigneur, Y. (2002). An eBusiness Model Ontology for Modeling eBusiness, In the Proceedings of the 15th Bled Electronic Commerce Conference - eReality: Constructing the eEconomy, Bled, Slovenia, June 17 - 19, 2002, pp. 75-91.

[15] Pastuszak, Z. (2003), "E-commerce customer service in Polish computer stores", Proceedings of the Second IASTED International Conference on Communications, Internet and Information Technology, ACTA Press, Scottsdale/Phoenix, AZ, pp. 54-60.

[16] Pastuszak, Z. (2004), "The philosophy of SCM in the new economy, net readiness in eSCM", Managing Global Transitions, International Research Journal, Vol. 2 No. 1, pp. 15-30.

[17] Pateli, A., \& Giaglis, G. (2003). 'A Framework for Understanding and Analysing e-Business Models', in Proceedings of the 16th Bled Electronic Commerce Conference - eTransformation, Bled, Slovenia, June 9-11 (CD-ROM -Proceedings).

[18] Petrovic, O., Kittl, C., \& Teksten, R.D. (2001). Developing Business Models for eBusiness, In the Proceedings of the International Conference on Electronic Commerce 2001, Vienna, Austria, October 31 - November 4.

[19] Shafer, Scott, M., H., Jeff Smith \& Jane C. Linder (2005). "The power of Business model", Business Horizons, 48, pp.199-207.

[20] Statistics Canada (1999), "A reality check to defining eCommerce". A report prepared by CGI for Statistics Canada.

[21] StatsCounter (2010). Microsoft Internet Explorer browser falls below $50 \%$ of worldwide market for first time. Accessed from: http://gs.statcounter.com/\#browser-ww-monthly-2 00909-201009 Retrieved 1st august 2012.

[22] Ticoll, D., Lowy, A., Kalakota, R. (1998). In: Tapscott, D. (Ed.), Blueprint to the Digital Economy: Creating Wealth in the Era of eBusiness. McGraw-Hill, New York.

[23] Timmers, P. (1999). Electronic Commerce: Strategies and Models for Business-to-Business Trading. Wiley.

[24] Turban, E. et al. (2004). Electronic Commerce, A Managerial Perspective, Prentice Hall,Upper Saddle River, NJ. 


\section{About the Authors}

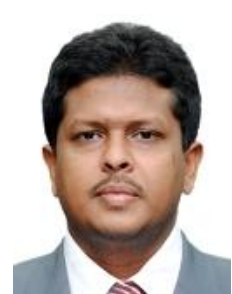

Premkumar.B has rich experience in IT, Manufacturing and Banking industry. He has presented Research papers in Management at International / National level seminars and symposiums and also conducted Team building and soft skills programs for the Corporate. Currently he is serving as Assistant Professor with School of Management, SRM University, Chennai, INDIA. His Research interests includes, Cross Cultural Management, Stress Management, E - Commerce, Social Research.

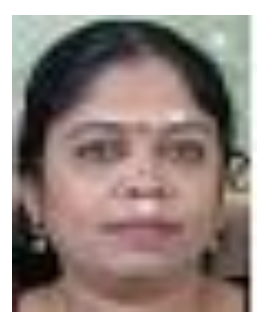

Dr. Kalpana is currently a Professor at School of Management, SRM University, Chennai, INDIA. She is an International Trainer in Behavioural Sciences and done programmes at Malaysia, US, Australia and UK. She has done breakfast shows with various channels and radio both India and Abroad. She has been a visiting faculty for a couple of Management colleges at UK. Won the Marfatti award for the best paper presented at the annual conference of the Indian Psychiatry Society in 1997. 